Received 20.04.2017 Reviewed 29.06.2017 Accepted 04.08.2017

A - study design

B - data collection

C - statistical analysis

D - data interpretation

$\mathbf{E}$ - manuscript preparation

F - literature search

\section{Assessment and mapping of desertification sensitivity with MEDALUS model and GIS - Case study: basin of Hodna, Algeria}

\author{
Fouzia BOUDJEMLINE ${ }^{1)}$ ABCDEF $\bowtie$, Ahcène SEMAR ${ }^{2) \text { ADF }}$
}

\author{
1) University of Sciences and Technology Houari Boumediene, Department of Geography and Spatial Planning, BP 32 \\ El Alia, 16111 Bab Ezzouar, Algiers, Algeria; e-mail: boudjemline.f@gmail.com \\ ${ }^{2)}$ National Superior Agronomic School, Department of Soil Science, El Harrach, Algeria; e-mail: achene_semar@yahoo.fr
}

\begin{abstract}
For citation: Boudjemline F., Semar A. 2018. Assessment and mapping of desertification sensitivity with MEDALUS model and GIS - Case study: basin of Hodna, Algeria. Journal of Water and Land Development. No. 36 p. 17-26. DOI: 10.2478/jwld-2018-0002.
\end{abstract}

\begin{abstract}
In Algeria, desertification risk is one of the main environmental and also social and economic problems. As much as 20 million hectares of northern Algeria are highly exposed and vulnerable to desertification with large areas falling into his 'severe' risk category, because the present massive destruction of vegetation and soils. This study aimed to use geographic information system (GIS) for mapping environmentally sensitive areas to desertification based on Mediterranean Desertification and Land Use (MEDALUS) approach in basin of Hodna, Algeria. Sensitivity is estimated with a modification of the MEDALUS environmentally sensitive area index (ESAI) which identifies such areas on the basis of an index (ESAI) that incorporates data on environmental quality (climate, vegetation, soil) as well as anthropogenic factors. This methodology allows the classification of land in critical, fragile and potentially sensitive areas. The results obtained show that $61 \%$ of the area is classified potentially sensitive to low sensitivity. These areas are particularly located in mountain areas. Spatially, the areas sensitive to degradation are as well in the lower region of the Hodna in Highlands consisting mostly of steppe route. The factors that could explain these variations of sensitivity are related mainly to changes in precipitation between the North and the South altitude and pressure of the population and livestock.
\end{abstract}

Key words: Algeria, desertification, ESAI, Hodna River basin, MEDALUS, soil sensitivity

\section{INTRODUCTION}

The United Nations Conference on Environment and Development [UNCED 1992], held in Rio (1992), has defined desertification as being: the degradation of land in arid, semi-arid and lands regions dry, due to various factors, including climate variations and human activities. In many countries, desertification is one of the most serious problems. Desertification affects one quarter of the area of the globe [UNCCD 2008]. In Africa, more than a billion hectares are moderately or seriously affected by desertification [THOMAS 1995]. Different models have been proposed to assess desertification at different scales with different approaches and settings methodology for assessment of desertification [FAO-UNEP 1984], model Turkmenistan [BABAEV 1985], GLASOD [OLDEMAN et al. 1991], MEDALUS [KOSMAS et al. 1999], DPSIR-FRAMEWORK [GIWA 2001] etc. The main processes of land degradation are related to vegetation cover, soil quality and erosion [FAO 1984]. Occur on a given area to certain elements of the natural ecosystem [soil, vegetation and water] are used beyond their specific thresholds [KIRKBY, KOSMAS 1999]. This requires a good knowledge of the interactions between the behaviour of economic actors, the potential of ecosystems and the mode of sharing resources.

BOUGUERRA et al. [2017] proposed a minimum data set for characterizing and monitoring soil indica- 

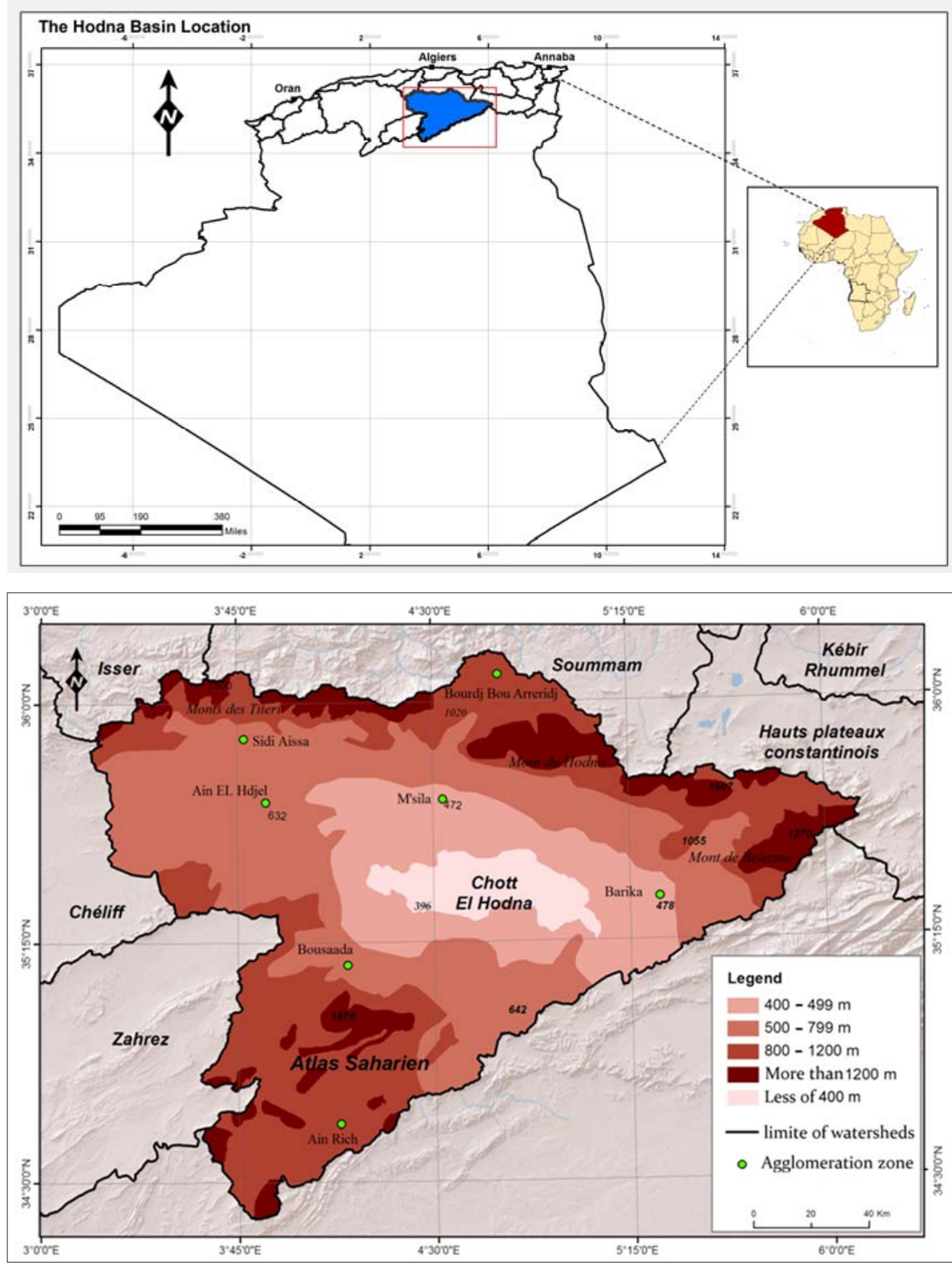

Fig. 1. Presentation and hypsometric map of the basin of Hodna; source: own elaboration

tor. Quantitative indicators of soil includes soil attributes and properties such as rainfall erosivity factor $(R)$, topography $(L S)$, soil erodibility $(K)$, covermanagement $(C)$ and support practice $(P)$.

In general, it is currently accepted that desertification is better explained by the combination of the socio-economic factors and biophysical, rather than factors by a simple variable [LAMBIN et al. 2009]. Moreover, the reduction in precipitation can activate some indirect causes of desertification through changes in land use [LAMBIN et al. 2009].

Many scientists agree that desertification is mainly due to human activities [CORNET 2001; KATYAL, VleK 2000; Le HouÈrou 1968; WARREN, AGNEW 1988]. However, the results of recent research on global climate change and the Mediterranean in particular tend towards a reduction in annual rainfall, an increase in average temperatures and an increase in their interannual variability and during the same season (increase in inter- and intra-annual) [ROUSSET, ARRUS 2004].

The estimate of sensitivity to land degradation in the Hodna basin was based on the model developed under the Mediterranean Desertification and Land Use (MEDALUS) project. DISMED [2003], mention that adapted to the conditions of Mediterranean environments, the model served as the basis for work in several countries such are (Portugal, Spain, Italy and Greece, Algeria, Egypt, Libya, Morocco, Mauritania, France, Tunisia and Turkey).

In this article, the main objective is; the stratification of the territory of the watershed in areas that are differentiated according to their degree of sensitivity to desertification. The approach is based on the use of GIS in the MEDALUS model applied to the basin of Hodna, Algeria. 


\section{MATERIALS AND METHODS}

\section{STUDY AREA}

The Hodna basin is approximately $250 \mathrm{~km}$ south-East of the capital, Algiers. It is located between $36^{\circ} 11^{\prime}$ and $34^{\circ} 29^{\prime} \mathrm{N}$ latitude and between $3^{\circ} 2^{\prime}$ and $6^{\circ} 11^{\prime}$ E longitude (Fig. 1). The basin straddles two distinct geological and geomorphological domains. To the north and north-east is the Tellian Atlas and to the South, the Saharan Atlas. The area of the Hodna basin is $26500 \mathrm{~km}^{2}$. The situation of the Hodna basin between two series of mountains to the North and the South organizes the basin around a closed almost flat basin at an altitude of $400 \mathrm{~m}$, and which receives the flow of surface waters in the region. At the centre of this basin, the Chott El Hodna has an area of $1150 \mathrm{~km}^{2}$.

The particularly mountainous northern slopes of the Hodna basin are subject to the Mediterranean climate influences, which explain a relative abundance of rainfall that varies between 400 and $800 \mathrm{~mm}$. The presence of important forests of oaks, cedars and pines of Aleppo is also explained by these topographic and climatic conditions favourable. The southern territories of the Hodna basin are however subject to the Saharan influences from the south. Their average annual rainfall varies between $100 \mathrm{~m}$ and $150 \mathrm{~m}$ across the basin. At the basin scale, the average rainfall of the basin is between 200 and $350 \mathrm{~mm}$ (rainfall map of the Hodna to 1:1 000 000) (National Agency of the Hydraulic Resources - Fr. Agence Nationale des Ressources Hydrauliques - ANRH, 1967-2014). It is also characterized by high temperatures in summer and low in winter. The lowest temperature is reached during the month of January with a value of $3.6^{\circ} \mathrm{C}$ and $4.02^{\circ} \mathrm{C}$, while the maximum is $38.8^{\circ} \mathrm{C}$ and $39.22^{\circ} \mathrm{C}$ in July or Two M'sila station, Bou-Saada (National Meteorological Office - Fr. Office National de la Météorologie - ONM, 1988-2014).

\section{ENVIRONMENTALLY SENSITIVE AREAS (ESAS) AND MEDALUS METHODOLOGY}

Methods were followed in this research based on MEDALUS (Mediterranean Desertification and Land Use) model that identify the sensitivity to desertification in Mediterranean ecosystems by an index of sensitivity to desertification and for mapping the environmentally sensitive areas (ESAs) obtained from the geometric average of four indexes of the soil quality, climate quality, vegetation quality, anthropic quality.

In the MEDALUS methodology the desertification related environmental quality of these factors is quality index $(S Q I)$, climate quality index $(C Q I)$, vegetation quality index $(V Q I)$ and anthropic quality in$\operatorname{dex}(A Q I)$.

Each of these environmental and a management factor is affected by the combination of several parameters that are considered in the computational algorithm according to the following formulas:

$$
\begin{gathered}
S Q I=(S T \cdot P M \cdot S \cdot D \cdot S D)^{1 / 5} \\
C Q I=(P P \cdot I A \cdot O R)^{1 / 3} \\
V Q I=(F R \cdot E P \cdot D R \cdot P C)^{1 / 4} \\
A Q I=(A P G \cdot D P \cdot D R \cdot D L)^{1 / 4}
\end{gathered}
$$

Where: $S T=$ soil texture, $P M=$ parental material, $S=$ slope gradient, $D=$ drainage, $S D=$ soil depth, $P P=$ annual precipitation, $I A=$ aridity, $O R=$ field orientation, $F R=$ fire risk, $E P=$ erosion protection, $D R=$ drought resistance, $P C=$ plant cover, $A P G=$ annual population growth rate, $D P=$ density of the population, $D R=$ density of the road network, $D L=$ density of livestock.

A score is assigned to the elements of a particular parameter in relation to their effect on the sensitivity to soil degradation and desertification processes as described by KOSMAS et al. [1999]. Scores for soil, climate, vegetation and anthropogenic factors are re-

\begin{tabular}{|c|c|c|c|c|}
\hline Factor & Class & Description & Characteristic & Index \\
\hline \multirow{4}{*}{ Texture } & 1 & good & $\mathrm{L}, \mathrm{SCL}, \mathrm{SL}, \mathrm{LS}, \mathrm{CL}$ & 1.0 \\
\hline & 2 & moderate & SC, SiL, SiCL & 1.2 \\
\hline & 3 & poor & $\mathrm{Si}, \mathrm{C}, \mathrm{SiC}$ & 1.6 \\
\hline & 4 & very poor & $\mathrm{S}$ & 2.0 \\
\hline \multirow{3}{*}{$\begin{array}{l}\text { Parent } \\
\text { material }\end{array}$} & 1 & good & $\begin{array}{c}\text { shale, schist, basic, } \\
\text { ultrabasic, } \\
\text { conglomerates, } \\
\text { unconsolidated }\end{array}$ & 1.0 \\
\hline & 2 & moderate & $\begin{array}{c}\text { limestone, marble, } \\
\text { granite, rhyolite, } \\
\text { ignimbrite, gneiss, } \\
\text { siltstone }\end{array}$ & 1.7 \\
\hline & 3 & poor & $\begin{array}{c}\text { sandstone } \\
\text { marl, pyroclastics }\end{array}$ & 2.0 \\
\hline \multirow{4}{*}{ Slope } & 1 & $\begin{array}{l}\text { very gentle } \\
\text { to flat }\end{array}$ & $<6 \%$ & 1.0 \\
\hline & 2 & gentle & $6-18 \%$ & 1.2 \\
\hline & 3 & steep & $18-35 \%$ & 1.5 \\
\hline & 4 & very steep & $>35 \%$ & 2.0 \\
\hline \multirow{3}{*}{ Drainage } & 1 & good & well drained & 1.0 \\
\hline & 2 & moderate & imperfectly drained & 1.2 \\
\hline & 3 & poor & poorly drained & 2.0 \\
\hline \multirow{4}{*}{$\begin{array}{l}\text { Soil } \\
\text { depth }\end{array}$} & 1 & deep & $>75 \mathrm{~cm}$ & 1.0 \\
\hline & 2 & moderate & $75-30 \mathrm{~cm}$ & 2.0 \\
\hline & 3 & shallow & $15-30 \mathrm{~cm}$ & 3.0 \\
\hline & 4 & very shallow & $<15 \mathrm{~cm}$ & 4.0 \\
\hline
\end{tabular}
ported in tables 1, 2, 3 and 4 .

Table 1. Classes and indices weights to assign different parameters used for the assessment of soil

Explanations: $\mathrm{L}=$ loam, $\mathrm{SCL}=$ sandy clay loam, $\mathrm{SL}=$ sandy loam, $\mathrm{LS}=$ loamy sand, $\mathrm{CL}=$ clay loam, $\mathrm{SC}=$ sandy clay, $\mathrm{SiL}=$ silty loam, $\mathrm{SiCL}=$ silty clay loam, $\mathrm{Si}=$ silt, $\mathrm{C}=$ clay, $\mathrm{SiC}=$ silty clay, $\mathrm{S}=$ sand.

Source: own elaboration acc. to KOSMAS et al. [1999] and BASSO et al. [2012].

For each index, a score ranging between 1, as good condition, and 2, as deteriorated condition, was assigned based on factorial scaling technique. Additionally, a zero value was assigned when the measure was not appropriate for an area or where that area was not classified. In most cases, a linear function ranging from 1 to 2 (extreme values) represents the variation 
of the indicators (score).The score values generally ranges between 1 and 2: low values indicate a high quality or, conversely, a low connection with desertification. The final $Q I$ is classified into three quality grades: high, moderate and low.

The SQI was computed based on the geometric mean of five fundamental parameters, which determine soil quality directly or indirectly, i.e. slope of the topographic surface, soil texture, soil depth, parent material, and drainage (Tab. 1) according to KOSMAS et al. [1999] and BASSO et al. 2012].

Slope gradient is classified in four classes according to the effect on soil erosion.

Soil texture is classified based on its sensitivity to desertification soil texture were very important for determining the land's susceptibility to desertification [VERA et al. 2007]. The severe class of soil degradation dominated the areas was characterized by sandy soil texture [WiJitKosum, YolpRAMOTE 2013]. The sandy texture of the soil resulted in a low water holding capacity. For this reason, soil texture is a key factor affecting the desertification risk of the area [WIJITKOSUM et al. 2013]

The $C Q I$ is assessed by considering the influence those parameters such as, mean annual precipitation, slope exposure and the index of aridity of BagnoulsGaussen. The aridity index is considered to be one of the most important indicators of areas that are susceptible to desertification [SAMPAIO et al. 2003].

Determination of the factor is based on rainfall map of the Hodna to 1:1 000000 (ANRH 1967-2014).

Annual precipitation is classified into three categories (Tab. 2) according SEPEHR et al. [2007] and VIEIRA et al. [2015] for aridity index.

Table 2. Classes and weighing indices for climate quality assessment

\begin{tabular}{|c|c|c|c|}
\hline Factor & Class & Class description & Index \\
\hline $\begin{array}{c}\text { annual } \\
\text { precipitation }\end{array}$ & 1 & $\begin{array}{c}>500 \mathrm{~mm} \\
250-500 \mathrm{~mm} \\
<250 \mathrm{~mm}\end{array}$ & $\begin{array}{l}1.0 \\
2.0 \\
3.0\end{array}$ \\
\hline Aridity & 2 & $\begin{array}{c}<50.0 \mathrm{~mm} \text { (hyper-arid) } \\
50-75 \mathrm{~mm} \text { (arid) } \\
75-100 \mathrm{~mm} \text { (semi-arid) } \\
100-125 \mathrm{~mm} \text { (dry sub-humid) } \\
125-150 \mathrm{~mm} \text { (moist sub-humid) } \\
>150 \mathrm{~mm} \text { (humid) }\end{array}$ & $\begin{array}{l}1.0 \\
1.1 \\
1.2 \\
1.4 \\
1.8 \\
2.0\end{array}$ \\
\hline $\begin{array}{l}\text { Field orienta- } \\
\text { tion (OR) }\end{array}$ & $\begin{array}{l}1 \\
2\end{array}$ & $\begin{array}{l}\text { NW-NE } \\
\text { SW-SE }\end{array}$ & $\begin{array}{l}1.0 \\
2.0\end{array}$ \\
\hline
\end{tabular}

Source: own elaboration acc. to SEPEHR et al. [2007] and VIEIRA et al. [2015].

According to the climate, we have consulted map of bioclimatic floors established by FAO [1972]. The layer of information related to the parameter "slope exposure" has been prepared from the digital model of terrain STRM.

The parameter "slope exposure" is also added and classified according to the methodology into two categories NW and NE, SW and SE with values of 1 and 2 .

The VQI computed based on the geometrical mean of four essential parameters of vegetation quality, fire risk, protection of soil from erosion by the dif- ferent types of vegetation, resistance to drought and percentage of vegetation cover. The scores are assigned considering the main types of vegetation and their percentage cover in the Mediterranean area classes and weighting indices of vegetation coverage, expressed in percentages, are given in Table 3 [BASSO et al. 2012; KOSMAS et al. 1999; SEPEHR et al. 2007].

Table 3. Classes and clues related to the quality of vegetation parameters

\begin{tabular}{|c|c|c|c|c|}
\hline Factor & Class & Description & Characteristics & Index \\
\hline Fire risk & $\begin{array}{l}1 \\
2 \\
3\end{array}$ & $\begin{array}{l}\text { low } \\
\text { moderate } \\
\text { very high }\end{array}$ & $\begin{array}{c}\text { sand, and Chott Sebkha } \\
\text { course, hills, } \\
\text { culture, forest }\end{array}$ & $\begin{array}{l}1.0 \\
1.3 \\
2.0\end{array}$ \\
\hline $\begin{array}{l}\text { Erosion } \\
\text { protection }\end{array}$ & $\begin{array}{l}1 \\
2 \\
3\end{array}$ & $\begin{array}{l}\text { very high } \\
\text { moderate } \\
\text { low }\end{array}$ & $\begin{array}{l}\text { mountainous } \\
\text { course, hills, } \\
\text { culture sand, } \\
\text { and Chott Sebkha }\end{array}$ & $\begin{array}{l}1.3 \\
1.8 \\
2.0\end{array}$ \\
\hline $\begin{array}{l}\text { Drought } \\
\text { resistance }\end{array}$ & $\begin{array}{l}1 \\
2 \\
3 \\
4\end{array}$ & $\begin{array}{l}\text { high } \\
\text { moderate } \\
\text { low } \\
\text { very low }\end{array}$ & $\begin{array}{l}\text { sand, and Chott Sebkha } \\
\text { course, hills } \\
\text { cultures, forest }\end{array}$ & $\begin{array}{l}1.2 \\
1.4 \\
1.7 \\
2.0\end{array}$ \\
\hline Plant cover & $\begin{array}{l}1 \\
2 \\
3\end{array}$ & $\begin{array}{l}\text { high } \\
\text { low } \\
\text { very low }\end{array}$ & $\begin{array}{c}>40 \% \\
10-40 \% \\
<10 \%\end{array}$ & $\begin{array}{l}1.0 \\
1.8 \\
2.0\end{array}$ \\
\hline
\end{tabular}

Source: own elaboration acc. to BASSO et al. [2012], KoSMAS et al. [1999] and SEPEHR et al. [2007].

The $A Q I$ has been calculated on the basis of four parameters; the annual population growth rate (19982008 ), the population density in 2008 , the density of the road network and the density of livestock. Table 4 shows the classes and assigned weighting indices for selected parameters for management quality assessment, according to [BASSO et al. 2012; KOSMAS et al. 1999].

Table 4. Classes and indices of parameters related to the anthropic quality

\begin{tabular}{|c|c|c|c|}
\hline Class & Factor & Class description & Index \\
\hline 1 & $\begin{array}{l}\text { the annual growth rate } \\
\text { of the population }\end{array}$ & $\begin{array}{c}>0 \% \\
0-1.5 \% \\
1.5-3 \% \\
3-6 \% \\
<6 \%\end{array}$ & $\begin{array}{l}1.0 \\
1.2 \\
1.4 \\
1.8 \\
2.0\end{array}$ \\
\hline 2 & $\begin{array}{l}\text { the density } \\
\text { of the population }\end{array}$ & $\begin{array}{c}<10 \text { person per } \mathrm{km}^{2} \\
10-20 \text { person per } \mathrm{km}^{2} \\
20-50 \text { person per } \mathrm{km}^{2} \\
>50 \text { person per } \mathrm{km}^{2}\end{array}$ & $\begin{array}{l}1.00 \\
1.33 \\
1.66 \\
2.00\end{array}$ \\
\hline 3 & $\begin{array}{l}\text { the density } \\
\text { of the road network }\end{array}$ & $\begin{array}{l}<0.5 \mathrm{~km} \cdot \mathrm{km}^{-2} \\
>0.5 \mathrm{~km} \cdot \mathrm{km}^{-2}\end{array}$ & $\begin{array}{l}1.0 \\
2.0 \\
\end{array}$ \\
\hline 4 & $\begin{array}{l}\text { the density } \\
\text { of livestock }\end{array}$ & $\begin{array}{c}<20 \text { heads per } \mathrm{km}^{2} \\
20-60 \text { heads per } \mathrm{km}^{2} \\
60-100 \text { heads per } \mathrm{km}^{2} \\
>100 \text { heads per } \mathrm{km}^{2}\end{array}$ & $\begin{array}{l}1.00 \\
1.33 \\
1.66 \\
2.00\end{array}$ \\
\hline
\end{tabular}

Source: own elaboration acc. to BASSO et al. [2012] and KOSMAS et al. [1999].

In these studies, the preliminary step is a careful selection of key - variables and indicators that should describe the actual state of the system and highlight the degradation changes and related effects in both time and spatial scales. The explicit definition of the minimum threshold values signalling the conversion towards an irreversible state of land degradation rep- 
resents a particularly complex issue. This is particularly the case in many semi-arid Mediterranean environments where the numerousness and variability of the factors influencing the process makes difficult to integrate and synthesize all of them in a unique value representing the threshold of degradation. Hence, it is necessary to assign to each triggering factor its own threshold value and to attribute to each one a different weight relevant to the role played in the desertification process in a space-specific and time-specific case [KOSMAS et al. 1999]. Therefore, the solution must consist in a balanced merger of different aspects of environmental stress ensuring a straightforward link among indicators themselves and the state and the tendency of the system they are representing. A minimum set of indicators, with the aim to identify of areas sensitive to desertification and subsequently the development of action plans to combat land degradation.

The environmental protection policies also contribute according to the degree with which they can affect the territory. The final environmentally sensitive areas index (ESAI) is calculated as the geometric average of the partial quality indices:

$$
E S A I=(S Q I \cdot C Q I \cdot V Q I \cdot A Q I)^{1 / 4}
$$

The range of values that the final ESAI can assume allows the classification of an area into categories and subcategories with varying degrees of desertification risk.

The desertification sensitivity map obtained from the overlay of the four previously discussed indicators. The index was classified in four sensitivity categories, absence (non affected) (1.00-1.22), low (1.23$1.30)$, moderate (1.31-1.4) and high (1.41-2.0).

\section{NUMERIC CARTOGRAPHY AND THEMATIC LAYERS}

Environmentally sensitive areas (ESAs) identification is an effective process, if availability and spatial uniformity and continuity of thematic spatial data are assured. It is based on the spatial and numerical combination of thematic layers into a GIS, which is the main tool of acquisition, storage, representation, processing and interpretation of geographic data.

The quantification of regions with different degradation sensitivity degrees was done based on the first four categories and on the actual analysis of classes, which correspond to moderate and high sensitivity. To this end, geostatistical methods were used by means of ArcGIS 10.1 software, according to the following steps:

- analysis of the significant factors and assignment of a numerical score;

- calculation of the relative quality index of each category (soil, climate, vegetation, management);

- production of related thematic maps and spatial overlaying for the computation of the ESAI;

- ESAs maps derivation.

We georeferenced all the geographical layers to the coordinate system UTM zone 31 North. In some cases we also needed to spatialize punctual data to derive thematic maps (e.g. soil thickness map as described below).

Therefore, digital maps from the observatory data base and maps elaborated ad hoc were used.

Listed below are the numerical and cartographic data from the database of the observatory of basin of Hodna, as well as maps and layers produced and used in this work.

Cartographic data from the database of the observatory:

- map of the basin of Hodna;

- regional topography;

- hydrography;

- map of the weather stations;

- map of bioclimatic floors established by FAO [1972];

- The Landsat TM satellite image (2009);

- soils of the Hodna at 1: 100000 map [FAO 1975];

- Digital Elevation Model (DEM);

- the map geological [CORNET 1954];

- map of the roads.

Numerical data extracted from the database of the observatory:

- map of the slope in percentage (derived from DEM);

- map of the exposure of slopes (derived from DEM);

- map of the main topographic features.

In order to map ESAs as described before, we elaborated the thematic layers to express the environmental (soil, climate, vegetation) and the anthropogenic factors by means of the scores. The MEDALUS model allows for a change in the number of parameters to be used for assessing the quality indices. We used five parameters for the soil, three for the climate, and four for the vegetation, four for the anthropogenic quality. In the sequence, the order from left to right is $S Q I, C Q I, V Q I$ and $A Q I$ and the value associated is the numbering of the classes or the first column from each score tables of the quality indices.

\section{RESULTS AND DISCUSSIONS}

The MEDALUS model was used for calculating the ESAI to determine the situation and tendency of desertification in basin of Hodna. The general methodology is fully described by [KOSMAS et al. 1999]. In general, the ESAI is a composite index that uses four indices of four categories including climate, vegetation, soil, and the socio-economic factors (management) field investigations and spatial data. Each parameter was weighted in relation to its impact and contribution to desertification process.

The MEDALUS model allows for the variation of the number of factors in the calculation of the partial quality indices, in relation to the availability of the data and thematic maps described above. The first three quality indices provide insight into the environmental conditions, while the last one expresses an assessment of the pressure resulting from the anthropogenic activities. Each of these indices is grouped into different uniform class with a weighting factor 
assigned to each class; then four layers are evaluated. After determining indices for each layer, the ESAs to desertification are defined by combining four quality layers. All data defining the four main layers are introduced in GIS and overlaid in accordance with the developed algorithm which takes the geometric mean to compile maps of ESAs to desertification. Several methods have been successfully applied for desertification analysis based on indicators and indices [SOMMER et al. 2011]. For example, the MEDALUS methodology, developed for the European Mediterranean environment, is widely used because of its simplicity and flexibility. The MEDALUS methodology is based on the environmentally sensitive area index (ESAI) [IzzO et al. 2013]. In order to identify areas potentially affected by land degradation, the method analyses four main variables: climate, soil, vegetation and land management [KOSMAS et al. 1999]. It has been validated on regional and local scales [BRANDT et al. 2003] and was applied to quantify the impact of mitigation policies against desertification [BASSO et al. 2012]. SYMEONAKIS et al. [2014] estimated the environmental sensitivity areas on the island of Lesvos (Greece) through a modified ESAI, which included 10 additional parameters related to soil erosion, groundwater quality, demographic and grazing pressure, for two dates (1990 and 2000). This study identified areas that are critically sensitive on the eastern side of the island mainly due to human-related factors that were not previously identified.

Although several studies have been conducted to detect desertification or to identify the drivers (indicators) of the process in critical hot spots in the Brazilian northeast [SAMPAIO et al. 2003], there have been no studies addressing the entire region. CREPANI et al. [1996] developed a methodology based on the concept of the eco-dynamic principles, proposed by [TRICART 1977], and on the relationship between morphogenesis and pedogenesis to identify areas that are susceptible to soil erosion. The author provided an integrated view of the physical environment and the conceptual basis for developing human-nature relationships. However, this study did not include socioeconomic and management indicators as parameters that can influence soil loss.

Therefore, the sensitivity of the model to variations of a certain factor decreases the greater the number of the elements used to calculate the quality index; consequently, the different weight of an individual factor may not reflect a real physical phenomenology, but rather the availability of data and the importance assigned to a single element in a given context. This empirical approach is, therefore, a limit to the objectivity of the evaluation of the degree of vulnerability obtained through the MEDALUS model.

Soil quality index (SQI). Table 5 contains the results for the three classes of the Hodna basin soil quality. The results show that the class of good quality is close to $65 \%$ of the total area. These soils are mainly located on low slopes around the valley areas. They are usually made of materials to balanced textures (Fig. 2). The soils of Medium quality account for $27 \%$, distributed mainly in the north western part of the basin. The soils of low qualities, which are very vulnerable to degradation, represent a small percentage, estimated at $8 \%$. They occupy areas where slopes are strong and are dominated by a fine texture which promote good drainage.

Table 5. Areas of the three classes of soil quality $(S Q I)$

\begin{tabular}{|c|l|c|c|}
\hline Class & \multicolumn{1}{|c|}{ Description } & Index & Area, \% \\
\hline 1 & high quality & $<1.13$ & 64.63 \\
\hline 2 & moderate quality & $1.13-1.45$ & 27.37 \\
\hline 3 & low quality & $>1.46$ & 8.00 \\
\hline
\end{tabular}

Source: own study.

Climate quality index (CQI). Table 6 shows the importance of the three classes of the Hodna basin climate quality.

Table 6. Area of the three classes of quality of climate (CQI)

\begin{tabular}{|c|l|c|c|}
\hline Class & \multicolumn{1}{|c|}{ Description } & Range & Area, $\%$ \\
\hline 1 & high quality & $<1.15$ & 16.78 \\
\hline 2 & moderate quality & $1.15-1.81$ & 21.35 \\
\hline 3 & low quality & $>1.81$ & 61.87 \\
\hline
\end{tabular}

Source: own study.

The application of Equation (2) accomplished a test card that shows that the study area is dominated by a climate of low quality with about $62 \%$ of area. This class is the steppe territories. The CQI describing a moderate quality is the order of $21 \%$, while highquality climate areas represent only $17 \%$ approximately. These are located along the northern limit of the watershed according to a band ranging from West to East (Fig. 3). According to the values of the CQI, the Hodna basin is an arid to semi-arid and potentially susceptible to desertification on $83 \%$ of its area.

Vegetation quality index (VQI). The results show that the vegetation cover remains low on almost $57 \%$ of the area of the study area, corresponding to cultivated steppes, degraded climatic steppes (Tab. 7). The map of vegetation quality index (Fig. 4) shows that areas with a good quality of the vegetation are located in forest regions of mountain with a rate of $35 \%$ (Tab. 7) of the total area. They are particularly located in the North-West at the borders with the basins of Isser and Chéliff, to the north in the level of reliefs of Bordj Bou Arreridj and Belezma, as well as in the Saharan Atlas. Some beaches are located around the depression of the Hodna. This class is predominantly occupied by forest vegetation, a real barrier against erosion and drought. The class of moderate quality, estimated at $8 \%$, is located at the level of the foothills of the mountains of the Hodna, Belezma and the Saharan Atlas. 


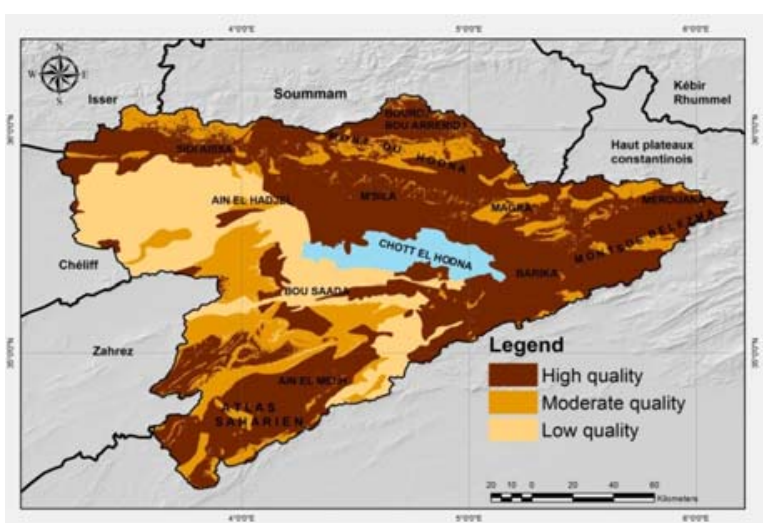

Fig. 2. Map of soil quality index; source: own study

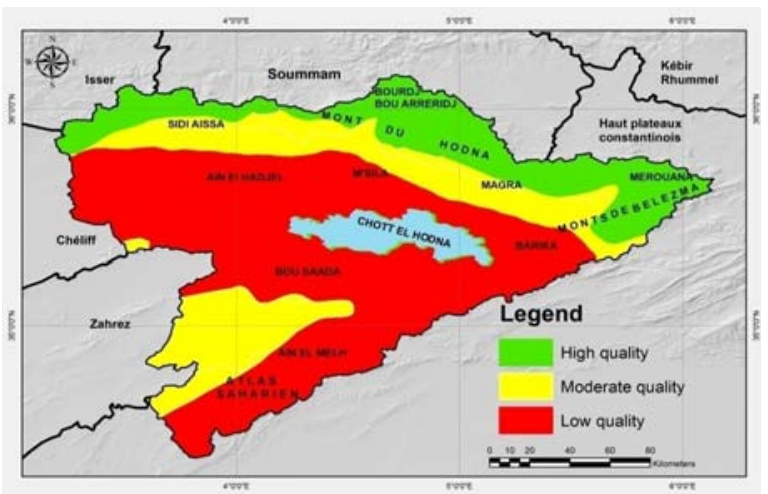

Fig. 3. Map of the climate quality index; source: own study

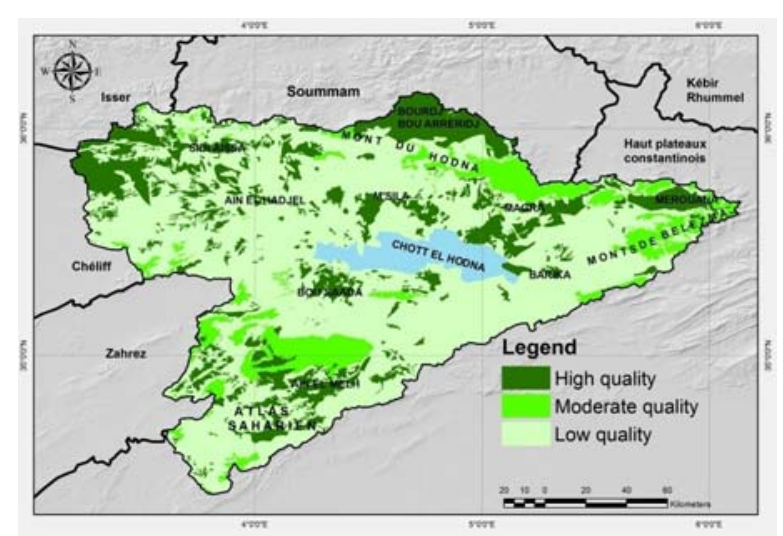

Fig. 4. Map of the vegetation cover quality index; source: own study

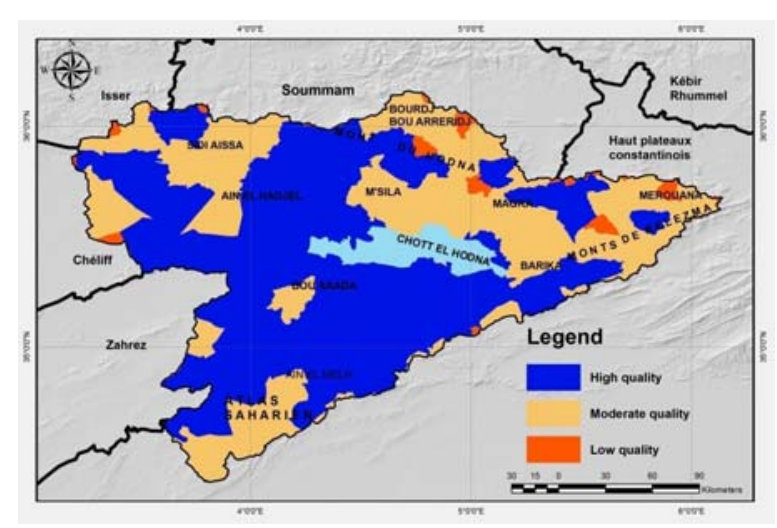

Fig. 5. Map of the anthropic quality index; source: own study

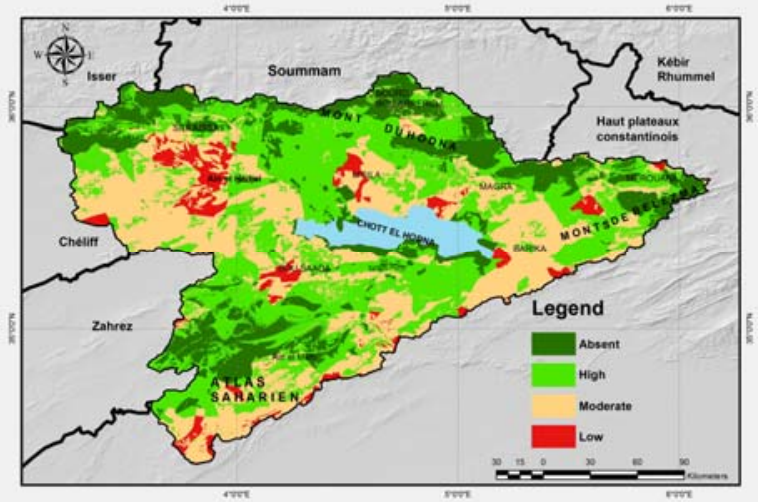

Fig. 6. Environmental sensitivity areas (ESAs) to desertification in Basin of Hodna; source: own study

Table 7. Areas of the three classes of quality of vegetation $(V Q I)$

\begin{tabular}{|c|l|c|c|}
\hline Class & \multicolumn{1}{|c|}{ Description } & Range & Area, \% \\
\hline 1 & high quality & $1.2-1.6$ & 35.26 \\
\hline 2 & moderate quality & $1.7-3.7$ & 8.01 \\
\hline 3 & low quality & $3.8-16$ & 56.73 \\
\hline
\end{tabular}

Source: own study.

Anthropic quality index (AQI). Map of the anthropogenic quality index (Fig. 5) obtained shows that the great part of the Hodna basin (78\%) presents a good quality; this is linked to the presence of agriculture based on extensive farming and to the low level of demographic pressure. The areas located mainly in the lower valley of the Hodna, where agriculture is intensive and anthropogenic pressure is relatively higher, show a quality of the management system medium to low (Tab. 8). This space is characterized by a lower risk of degradation. This is to be relativized because the entire basin knows a very large dispersion of human occupation. This translates the starting points of spatial and environmental mutations.

Table 8. Areas of the three classes of anthropic quality $(A Q I)$

\begin{tabular}{|c|l|c|c|}
\hline Class & \multicolumn{1}{|c|}{ Description } & Range & Area, $\%$ \\
\hline 1 & high quality & $1-1.25$ & 78 \\
\hline 2 & moderate quality & $1.26-1.50$ & 14 \\
\hline 3 & low quality & $>1.51$ & 8 \\
\hline
\end{tabular}

Source: own study.

Environmental sensitivity areas index (ESAI). In the cartographic distribution of the ESAI, while taking into consideration the same partial quality indices we were able to adopt two different strategies. Table 9 gives importance in terms of area of four types of sensitivity to desertification in the basin. Classes are type high sensitivity, sensitive, weak type and unclassified type.

The sensitivity map obtained (Fig. 6) shows that the class corresponding to areas not threatened at the risk of desertification, occupies $21,28 \%$ of the total area. These zones are located on the forest massifs. This low sensitivity is due to the good quality of soil 
Table 9. Ranges and description of sensitivity to desertification areas

\begin{tabular}{|c|l|c|c|}
\hline Class & \multicolumn{1}{|c|}{ Description } & Range & Area, \% \\
\hline 1 & high (very sensitive) & $1.41-2.00$ & 17.42 \\
\hline 2 & average (sensitive) & $1.31-1.40$ & 50.82 \\
\hline 3 & low (not very sensitive) & $1.23-1.30$ & 10.48 \\
\hline 4 & absence (non affected) & $1.00-1.22$ & 21.28 \\
\hline
\end{tabular}

Source: own study.

and vegetation. The class of low sensitivity to desertification is much less common $(10 \%)$. The areas are located at the level of the mountainous reliefs of the Hodna basin and particularly the Hodna mountains, Belezma, the northern part of the Saharan Atlas and the north-western reliefs delimiting the Isser basin. More than half of the territory of the Hodna basin, $61 \%$ is classified as potentially sensitive to lowsensitivity. These areas are particularly located at the bottom of reliefs and are particularly extensive in the regions of Ain El Hadjel, Boussada, M'Sila, Barika and the south of Ain El Melh. He is encountered the dominance of the class of poor quality of the climate, corresponding to the bioclimate arid on almost all of the study area, thus influencing the distribution, type and condition of vegetation, and, consequently, the rate of soil degradation. Areas very sensitive to desertification correspond to a very small area with only $17 \%$, they are moderately exposed to the phenomenon of desertification are located south of the town of M'Sila and North-East of the town of Bousaada, with an index between 1.41-2.0, this sensitivity is due to the poor quality of the climate, the poor quality of the soil and the poor quality of the vegetation and the socio-economic factor corresponding to cropland and cultivation.

\section{CONCLUSIONS}

In this study, we mapped the risk of desertification by adaptation of the MEDALUS method and use of GIS tools in the Hodna basin. These latter enabled the ease of calculations of indicators in the MEDALUS method by a multitude of functions of spatial analyses and methods of classification. Map of sensitivity obtained shows that more than half of the territory of the Hodna basin, or $61 \%$ is classified as potentially sensitive to little sensitive. The geographical distribution of the areas of risk corresponds to various degrees of sensitivity to phenomena related essentially to the topography, geographical position in relation to the quality of the climate and human pressure. Areas submitted with a strong sensitivity to desertification are either those subject to strong anthropogenic pressure, or those affected by high aridity, or by the simultaneous combination of both climatic and anthropogenic factors. The maps produced by the model are a mode of communication of a measured and geo-referenced reality, by a GIS, to which one must present arguments of "ground truth".

The study of the mapping of the risk of desertification by adaptation of the MEDALUS method and the use of GIS tools suffers, here, from a number of limits. These limits are, firstly, due to the fact that it is impossible for any researcher or even research team approach all causal relations contained in this research. Then, these inadequacies are related to available data and the data that it is possible to collect on the field. Regarding the shortcomings of the MEDALUS approach, it is useful to note that the method of calculating the index of sensitivity to desertification is based on assumptions that are not always easy to verify on the ground.

\section{REFERENCES}

BABAEV A.G. 1985. Methodological principals of desertification processes assessment and mapping. Ashgabat, Turkmenistan. Desert Research Institute, Ashgabat pp. 72.

Basso B., De Simone L., Cammarano D., Martin E.C, Margiotta S., Grace P.R., Yeh M.L., Chou T.Y. 2012. Evaluating responses to land degradation mitigation measures in Southern Italy. International Journal of Environmental Research. Vol. 6 p. 367-380.

Bouguerra H., Bouanani A., Khanchoul K., Derdous O., TACHI S.E. 2017. Mapping erosion prone areas in the Bouhamdane watershed (Algeria) using the Revised Universal Soil Loss Equation through GIS. Journal of Water and Land Development. No. 32 p. 13-23. DOI 10.1515/jwld-2017-0002.

BRANDT J., GEESON N., IMESON A. 2003. A desertification indicator system for Mediterranean Europe. Bruxelles, Belgium: DESERTLINKS Project, Document and accompanying CD-ROM demonstrating the prototype Desertification Indicator System, prepared for distribution at the UNCCD COP6, Havana, August, 2003 pp. 79.

CORNET A. 2001. La désertification à la croisée de l'environnement et du développement : un problème qui nous concerne [Desertification at the crossroads of environment and development: A problem that concerns us]. Paris. Comité Scientifique Français de Lutte contre la Désertification pp. 32.

Crepani E., Medeiros J.S., Azevedo L.G, Duarte V., Hernandez P., Florenzano T. 1996. Curso de sensoriamento remoto aplicado ao zoneamento ecológico-econômico [Remote sensing course applied to ecological-economic zoning]. São José dos Campos - SP. INPE pp. 25.

DISMED 2003. Système d'information sur la désertification en appui aux Programmes d'Action Nationaux dans la Méditerranée [Desertification Information System to support National Action Programmes in the Mediterranean]. Séminaire Technique DISMED sur les besoins cartographiques des décideurs - cartographie de la dynamique de la désertification: Compte rendu de la réunion. 12-14.06.2003 Sesimbra, Portugal pp. 17.

FAO 1972. Etude des ressources naturelles et expérimentation et démonstration agricoles dans la région du Hodna. Algérie, étude phytoécologique du Hodna [Natural resources study and agricultural experimentation and demonstration in the Hodna region. Algeria, Phytoecological study of Hodna]. Vol. 1. Rome, Italy. RAP27679 pp. 138.

FAO 1975. Etudes des ressources naturelles et expérimentation et démonstration agricoles dans la région du Hodna: Algérie: Les sols du Hodna: Carte pédologique. 
Carte des aptitudes culturales [Natural resources studies and agricultural experimentation and demonstration in the Hodna region: Algeria: Soils of Hodna: Soil Map. Map of cultural abilities]. Vol. 2. Rome, Italy. RAP43092 pp. 154

FAO-UNEP 1984. Provisional methodology for assessment and mapping of desertification. Rome (Italy). Food and Agriculture Organization of The United Nations, United Nations Environmental Programme. ISBN 9251014426 pp. 84.

GIWA 2001. DPSIR framework for state of environment reporting (Driving Forces-Pressures-State-ImpactsResponses). Global International Water Assessment, European Environment Agency. ISBN 97911952673 pp. 104.

Izzo M., Araujo N., Aucelli P.P.C., Maratea A., SanCHEZ A. 2013. Land sensitivity to desertification in the Dominican Republic: an adaptation of the ESA methodology. Land Degradation and Development. Vol. 24. Iss. 5 p. 486-498. DOI 10.1002/ldr.2241.

KATYAL J.C. VLEK P.L.G. 2000. Desertification: concept, causes and amelioration. ZEF - Discussion papers on development policy. No 33. Bonn, Germany pp. 65.

KIRKBY M., KosmaS C. 1999. Introduction. In: The MEDALUS project: Mediterranean desertification and land use. Manual on key indicators of desertification and mapping environmentally sensitive areas to desertification. Project report. Eds. C. Kosmas, M. Kirkby, Geeson N. Luxembourg. European Commisson. Office for Official Publications of the European Communities p. 1-8.

Kosmas C., Ferrara A., Briasouli H., Imeson A. 1999. Methodology for mapping Environmentally Sensitive Areas (ESAs) to desertification. In: The MEDALUS project: Mediterranean desertification and land use. Manual on key indicators of desertification and mapping environmentally sensitive areas to desertification. Eds. C. Kosmas, M. Kirkby, N. Geeson. European Union 18882 p. $31-47$.

Kosmas C., Gerontidis St., Detsis V., Zafiriou Th., MARATHIANOU M. 1999. The island of Lesvos (Greece). In: The MEDALUS Project: Mediterranean desertification and land use. Manual on key indicators of desertification and mapping environmentally sensitive areas to desertification. Eds. C. Kosmas, M. Kirkby, N. Geeson. European Union 18882 p. 66-73.

LAMBIN E.F., GEIST H.J., REYNOLDS J.F., STAFForD-SMith D.M. 2009. Coupled human-environment system approaches to desertification: Linking people to pixels. In: Recent advances in remote sensing and geoinformation processing for land degradation assessment. Eds. A. Roder, J. Hill. London. CRC Press p. 3-14.

LE HouÈrou H.N. 1968. La désertisation du Sahara septentrional et des steppes limitrophes (Lybie, Tunisie, Algérie) [The desertification of northern Sahara and neighboring steppes (Libya, Tunisia, Algeria)]. Conseil du Tutelle colloque Hammamet et annales Algériennes de géographie. Vol. 3(6) p. 2-27.

Oldeman L.R., HakKelingr.T.A., Sombroek W.G. 1991. World Map of the Status of Humaninduced Soil Degradation (GLASOD): An explanatory note. Wageningen. International Soil Reference and Information; Centre; Nairobi, United Nations Environment Programme pp. 27.

RouSSET N., ARRUS R. 2004. Economie de l'adaptation au changement climatique et agriculture dans le bassin Méditerranéen. Environnement et identité en Méditerranée. [Economics of adaptation to climate change and agriculture in the Mediterranean basin. Environment and identity in the Mediterranean]. IVe Congrès international. Corse, Juillet 2004. Universita di Corsica Pasquale Paoli pp. 8.

Sampaio E.V.S.B, Araujo M.S.B., Sampaio Y.S.B. 2003. Propensão à desertificação no semi-árido Brasileiro [The desertification propensity in the Brazilian semi-arid region]. Revista de Geografia. Vol. 22. No. 2 p. 59-76.

SEPEHR A., HASSANLi A.M., EkHtesasi M.R., JAMAli J.B. 2007. Quantitative assessment of desertification in south of Iran using MEDALUS method. Environmental Monitoring and Assessment. Vol. 11134. Iss. 1-3 p. 243-254.

Sommer S., Zucca C., Grainger A., Cherlet M., Zougmore R., Sokona Y., Hill J., Della Peruta R., RoehRIG J., WANG G. 2011. Application of indicator systems for monitoring and assessment of desertification from national to global scales. Land Degradation and Development. Vol. 22. Iss. 2 p. 184-197. DOI 10.1002/ ldr. 1084.

SymeOnAKis E., Karathanasi N., Koukoulas S., PanaGOPOULOS G. 2014. Monitoring sensitivity to land degradation and desertification with the environmentally sensitive area index: the case of Lesvos Island. Land Degradation and Development. Vol. 22 p. 184-197. DOI 10.1002/ldr.2285.

Thомаs D.S.G. 1995. Desertification: Causes and processes. In: Encyclopaedia of environmental biology. Vol. 1. Ed. W. A. Nierenberg. San Diego. Academic Press p. $463-473$.

TRICART J. 1977. Ecodinâmica [Ecodynamics]. Rio de Janeiro. IBGE-SUPREN pp. 9.

UNCCD 2008. Desertification - Coping with today's global challenges in the context of the strategy of the United Nations Convention to combat desertification. Unites Nations Convention to Combat Desertification. Report on the High Level Policy Dialogue. Bonn, Germany pp. 47.

UNCED 1992. Earth Summit'92. The UN Conference on Environment and Development. Rio de Janeiro. The Regency Press, London p. 15-17.

Vera M., Sierra M., Diez M., Sierra C., Martinez A., Martinez F.J., Aguillar J. 2007. Deforestation and land use effects on micromorphological and fertility changes in acidic rainforest soils in Venezuelan Andes. Soil and Tillage Research. Vol. 97. Iss. 2 p. 184-194.

Vieira R.M.S.P., TOMasella J., Alvala R.C.S., Sestini M.F., AfFonso A.G., Rodriguez D.A., BARbosa A.A., Cunha A.P.M.A., Valles G.F., Crepani E., De Oliveira S.B.P., De Souza M.S.B., Calil P.M., Carvalho M.A., Valeriano D.M., Campello F.C.B., Santana M.O. 2015. Identifying areas susceptible to desertification in the Brazilian northeast. Solid Earth. Vol. 6 p. 347-360.

WARren A., AgNew C. 1988. An assessment of desertification and land degradation in arid and semi-arid areas. Drylands Program. International Institute for Environment and Development. London, Ecology and Conservation Unit, University College Paper. No. 2 pp. 30.

WiJitkosum S., KroutnoI L., Yolpramote K. 2013. Factors affecting the desertification in Huay Sai Royal Development Study Center, Thailand. Journal of Environmental Research and Development. Vol. 7. No 4 p. 1439-1443.

Wijitkosum S., Yolpramote K. 2013. Clustering soil properties for appropriate soil improvement in Huay Sai Royal Development Study Center, Thailand. In: 6th TSAE International Conference; 1-4.04.2013 Hua Hin, Thailand. SWE- 03 p. 175-178. 


\section{Fouzia BOUDJEMLINE, Ahcène SEMAR}

Ocena i mapowanie wrażliwości pustynnienia za pomocą modelu MEDALUS i GIS Studium przypadku: dorzecze Hodna, Algieria

\section{STRESZCZENIE}

Ryzyko pustynnienia jest jednym z głównych problemów środowiskowych, ale także problemem społecznym i ekonomicznym. Aż $20 \mathrm{mln}$ ha w północnej Algierii zagrożonych jest pustynnieniem, a na znacznych obszarach zagrożenie występuje w stopniu poważnym $\mathrm{z}$ powodu niszczenia roślinności i gleb na masową skalę. W badaniach wykorzystano system informacji geograficznej GIS i model MEDALUS (ang. - MEditerranian Desertification And Land USe) i zastosowano je w odniesieniu do basenu Hodna w Algierii. Wrażliwość oceniano z zastosowaniem zmodyfikowanego indeksu środowiskowej wrażliwości obszaru (ESAI), który uwzględnia dane o jakości środowiska (klimat, roślinność, gleba) oraz czynniki antropogeniczne. Ta metoda umożliwia klasyfikację obszarów na: krytycznie zagrożone, słabo i potencjalnie wrażliwe. Uzyskane wyniki dowodzą, że $61 \%$ badanego obszaru to ziemie potencjalnie wrażliwe lub o niskiej wrażliwości. Są to głównie tereny górzyste. Obszary wrażliwe na degradację znajdują się także w niżej położonych regionach Hodna o cechach stepu. Czynnikami, które objaśniają zmienność wrażliwości na pustynnienie, są różnice w opadach pomiędzy północą a południem oraz presja ludności i zwierząt inwentarskich.

Słowa kluczowe: Algieria, basen rzeki Hodna, indeks ESA, MEDALUS, pustynnienie, wrażliwość gleb 